\title{
Going back: Radiation and intentions to return amongst households evacuated after the Great Tohoku Earthquake
}

\author{
Alistair Munro \& Shunsuke Managi
}

September 2014

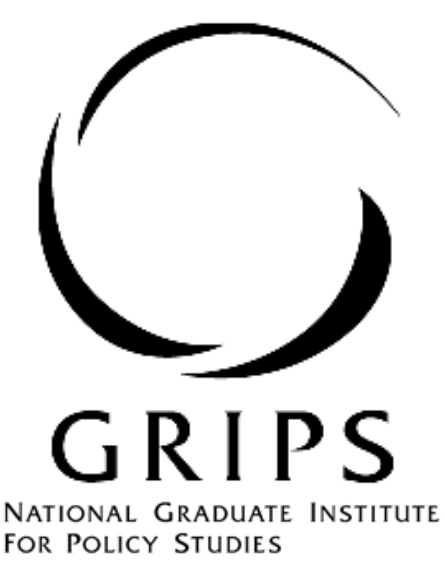

National Graduate Institute for Policy Studies

7-22-1 Roppongi, Minato-ku,

Tokyo, Japan 106-8677 


\title{
Going back: Radiation and intentions to return amongst households evacuated after the Great Tohoku Earthquake
}

\author{
Alistair Munro $^{1}$ \\ National Graduate Institute for Policy Studies (GRIPS), Roppongi 7-22-1, Minato-ku, Tokyo, Japan, \\ 106-8677. \\ Shunsuke Managi \\ Graduate School of Environmental Studies, Tohoku University, Sendai, Miyagi, Japan, 980-8579.
}

\begin{abstract}
Based on a survey conducted with evacuees from the Fukushima radiation-affected region of Japan we examine intentions to return, eventually to the family homes. Many respondents do not intend to return, particularly those with children, but higher income households and those who evacuated to the same town are more likely to go back. Intentions are only weakly responsive to changes in radiation, suggesting that the ongoing policy of active decontamination may have only a limited impact on eventual resettlement.
\end{abstract}

Keywords: household return, nuclear radiation, family, Fukushima, evacuees, Japan

Acknowledgements: We would like to thank Shinya Horie for survey preparation. The research was funded by a Grant-in-Aid for Scientific Research from the Japanese Ministry of Education, Culture, Sports, Science and Technology (MEXT) Specially Promoted Program.

\footnotetext{
${ }^{1}$ Corresponding Author. Email address: alistair-munro@grips.ac.jp
} 


\section{Introduction}

In the wake of the 2011 Great Tohoku Earthquake in Japan and the subsequent tsunami and the radioactive discharges from the damaged nuclear power plant in Fukushima prefecture, many residents moved out of their original homes. In this research we investigate intentions to return amongst a sample of those affected. Our particular focus is on the relationship between radiation risk and intentions.

While there is a relatively large literature on intentions to return after a disaster (e.g. Landry et al. (2007), Elliott and Pais (2006) for hurricanes and floods, Rofi et al. (2006) for tsunami), not surprisingly the research literature on return after nuclear accidents is sparse (Chernobyl Forum (2006)). Yet a clear understanding of the factors that affect resettlement is important for the purposes of policy towards decontamination and rehabilitation (Strand et al. (1989), Munro (2013)) not least because prolonged evacuation has been linked to the social ills of stress, mental illness and unemployment (Lehmann and Wadsworth (2011), Stephan (2005)). From the viewpoint of identifying the effect of perceived radiation risk on behaviour, a complicating feature of those who left their homes in and around Fukushima is that many householders were affected by both tsunami and radiation. A number of the communities which have undergone evacuation face the sea and suffered major losses of life from flooding and inundation the tsunami. For this reason we sample across a variety of communities with different levels of exposure to the events in March 2011.

\section{Background \& Methods}

We use a latent variable approach to model intention to return. A feature of previous research on return intentions after a disaster or sharp deterioration in environmental quality is the presence of quite stark differences between demographic groups (Landry et al. (2007)). Our general specification of the statistical model underlying intended behaviour is therefore:

$$
y_{i j}=\beta_{0}+\sum X_{i}^{\prime} \beta+r_{j}\left(\sum Z_{i}^{\prime} \gamma\right)+c_{j}\left(\sum W_{i}^{\prime} \theta\right)+\varepsilon_{i}
$$

In this equation $y_{i}$ is a latent variable indicating household i's propensity to return to location $\mathrm{j}, \beta_{0}$ is a constant, $X_{i}$ is a vector of attributes for household i, $\beta$ is its associated parameter vector, $r_{j}$ represents the radiation levels ( $\mathrm{mSv}$ per year) at location $\mathrm{j}, Z_{i}$ is a vector of household variables that may affect attitudes to the historical risk with $\gamma$ is its associated vector of parameters, $c_{j}$ is a measure of the impact on the tsunami and earthquake on a location, $W_{i}$ and $\theta$ are associated vectors of household attributes 
and parameters respectively and $\varepsilon_{i}$ is an error term, which is assumed to have a standard normal distribution. Note that many of the elements of $X, Z$ and $W$ may be the same.

\subsection{The Sample}

Data was obtained in February 2012 through randomly selected face-to-face interviews in three prefectures. For the purposes of this study we use data only from Fukushima and the adjoining Miyagi prefectures, giving $n=520$. Fukushima is the area most affected by radiation while Miyagi is the area most affected by the tsunami. Many householders were affected by both tsunami and radiation risk. Therefore, our sample includes communities with a different mix of experiences.

For tsunami exposure we construct a dummy variable where for districts with no sea border the variable is coded as zero. In addition we use death rate - the number of deaths divided by the prior population using Fire and Disaster Management Agency (2014) data. The figures for fatalities include some people who died from non-tsunami causes, but overwhelmingly deaths were linked to the tsunami rather than the prior earthquake. For radiation exposure we use "Air Dose Rate Readings at 2,200 Locations in Fukushima Prefecture and Neighboring Prefectures (From June 2011 to July 2011)" downloaded from https://mapdb.jaea.go.jp/mapdb/ . This is an extensive official survey carried out in the summer of 2011 covering more sites than some of the earliest measurement exercises. For each identifiable city or town we take the mean of the readings for that town. For some low-dose (i.e. $<1 \mathrm{mSv}$ per year) unsampled areas in Miyagi prefecture we take figures from a sample later in the same year (December 2011).

We present basic data about the sample in Table 1 where most variables are self-explanatory. However, 'location' refers to whether the respondent's temporary address is in the same municipality as their original house (coded as ' 1 ') or in a different location (coded as ' 2 '). 'Nursing care' indicates where there are elderly people in the house who need medical care on a continual basis. 'Evacuation zone' refers to respondents who were compulsorily evacuated from higher radiation areas. 'Community participation' refers to the degree of involvement in local groups.

It can be seen from Table 1 that nearly $90 \%$ of the sample came from towns that had some exposure to the tsunami and that less than half the sample (38\%) currently intend to return to their old homes despite the fact that most of the participants had deep roots in the area including children in school, long years of residence, some participation in community activities and not being the first generation to reside in the area (59\% of the sample). Approximately $58 \%$ of evacuees had moved to a different location in the same municipality, with this pattern particularly common amongst the larger cities (e.g. Ishinomaki and Sendai) and in Miyagi prefecture. Concern about radiation varied across the sample, but the most common view (48\%) was that residents had to worry a little, but did not have to take special 
precautions with food ingredients. The most common stated occupation was company worker followed by currently without work, retired and full-time housewife. Nearly all participants (98\%) had access to the computer and nearly all (99\%) reported that they had some internet use.

Living in the same town may mean some raised level of current radiation dose, compared to individuals who have moved to another town. At the same time the decision to stay in the same town may be endogenous (for instance depending on community links, whether children can still attend their usual school and so on) and this may yield biased estimation results. One potential solution is to instrument the 'location' variable with another variable that is predictive for location but has no direct effect on intention to return. The nature of the context means that it is difficult to find an instrument for 'location' - most candidate variables such as the age of the subject or their connection to the community may also have a direct effect on the intention to return. As a consequence we use the mean of the location variable for other people from the same town as the instrument (Fisman and Svensson, 2007) in one version of the statistical model.

\section{Results}

In Table 2, all equations except the last are probit with errors clustered at the level of the town. The 'simple' model omits interactions. The model labelled 'radiation' has an interactive term only for radiation. The third equation allows for interactive terms for both radiation and death rates. The next two models with the smaller sample sizes are respectively, one confined to those individuals who stated that it was possible to move back into their house and one that is confined to Fukushima residents. The final column ('IV') is a linear probability model in which the variable 'location' is treated as endogenous and it is instrumented using the mean of the location variable for other people from the same town (Fisman and Svensson, 2007). A robust regression-based test does not reject the null of exogeneity $(\mathrm{p}=0.162)$ at standard significance levels.

The row labelled 'marginal effect of $\mathrm{R}$ ' reports the estimate of an increase in radiation level evaluated at the mean values of all variables. The coefficient is significant and stable across specifications, including the IV model. Typically a $1 \mathrm{mSv} /$ year rise decreases the probability of return by about 0.3 percentage points. Since the range of potential doses is about $150 \mathrm{mSv} / \mathrm{year}$, then moving from the lowest dose area to the highest dose area reduces the probability of return by approximately 45 percentage points. 
The p-values for a likelihood ratio tests for joint significance of the interactive terms are given in the final row of Table $2 .{ }^{2}$ In both cases the null of no interactive effects is just accepted at standard levels of significance. Having more children in the household is associated with a lower probability of return, but in other cases the interactive terms with death-rate and radiation level are not generally meaningful. The intention to return is higher for households with higher income and for households who evacuated to the same town. It is understandably lower for individuals in tsunami-affected towns, but not related directly to community participation levels or years of residence. Individuals who had experienced compulsory evacuation were much more likely to state an intention to return. This suggests that without compulsion many residents may not have left the radiation affected areas.

It is the firm intention of the Japanese government to prepare for resettlement by decontaminating most towns surrounding the nuclear power plant (Hardie and McKinley, 2014). In Figure 1 we use the estimated model to simulate the effects of four policies on return intentions within our sample. The vertical axis shows the mean estimated probability of return. Policy 1 is the baseline, based on the measured 2011 radiation levels and stated intentions. Policies 2-4 show progressively more ambitious targets: annual dose in all areas reduced to a maximum of 20,5 and $1 \mathrm{mSv}$ per year respectively. These levels represent important thresholds for current decontamination and resettlement policies in Japan (Moriya 2011). In particular, $1 \mathrm{mSv} /$ year is the long run target for exposure while $20 \mathrm{mSv} /$ year has been the evacuation threshold and the point at which resettlement is considered. In the figure, we show the estimates separately for evacuated and non-evacuated households and for households with zero and two children. In all cases, lower targets are associated with higher intention to return rates. Families with two children have the lowest mean intention to return and the gain in the percentage of participants intending to return found by going from 2011 radiation levels to a cap of $1 \mathrm{mSv}$ per year is 11.2 percentage points. For non-evacuated families the gain is 7.8 percentage points and 15.1 percentage points for the evacuated. Across the whole sample, just $62.5 \%$ intend to go back even if radiation exposure is reduced to a maximum of $1 \mathrm{mSv}$ per year.

\section{Discussion and Conclusions}

We find a complex relationship between radiation levels and an intention to return that is mediated by family structure and economic circumstances. On the whole families with children are less likely to intend to return and more sensitive to changes in radiation risk. The impact of radiation levels on intentions to return is stable across specifications and suggests that a policy of simply lowering radiation will have only a modest impact on return rates. A large scale effort is currently underway in Fukushima

\footnotetext{
${ }^{2}$ For this the models are re-estimated without clustered errors.
} 
to decontaminate soils, public infrastructure such as schools and roads as well as private dwellings. A major justification of the policy is the belief that nearly all residents will return once evacuation orders are removed and radiation exposure is significantly lowered. These results suggest that either further effort will be needed to persuade many people to return, or that the policy may be ineffective in its ultimate aim. 


\section{References}

Chernobyl Forum, 2006. Health, Environmental and Socio-Economic Impacts and Recommendations to the Governments of Belarus, the Russian Federation and Ukraine: 2003-2005 Second revised version. World Health Organization (WHO).

Elliott, J. R., Pais, J., 2006. Race, class, and Hurricane Katrina: Social differences in human responses to disaster. Social Science Research 35 (2), 295-321.

Fire and Disaster Management Agency, 2014. (in Japanese) 149th Report on the Great East Japan Earthquake. URL http://www.fdma.go.jp/bn/higaihou/pdf/jishin/149.pdf

Fisman R. and Svensson J., 2007, Are corruption and taxation really harmful to growth? Firm level evidence. Journal of Development Economics, 83(1), 63-75.

Hardie, S.M.L. and McKinley, I. G., 2014, Fukushima remediation: status and overview of future plans, Journal of Environmental Radioactivity, 133, 75-85, http://dx.doi.org/10.1016/j.jenvrad.2013.08.002.

Landry, C. E., Bin, O., Hindsley, P., Whitehead, J. C., Wilson, K., 2007. Going home: Evacuationmigration decisions of Hurricane Katrina survivors. Southern Economic Journal, 326-343.

Lehmann, H., Wadsworth, J., 2011. The impact of Chernobyl on health and labour market performance. Journal of health economics 30 (5), 843-857.

Moriya, Masaru, 2011, Remediation Efforts in Japan, Presentation at OECD "International Symposium on Decontamination: Towards the Recovery of the Environment," http://www.oecd-nea.org/press/2011/NEWS-07-presentations.html

Munro, A., 2013. The economics of nuclear decontamination: assessing policy options for the management of land around Fukushima dai-ichi. Environmental Science and Policy 33 (0), 63 75, url="http://www.sciencedirect.com/science/article/pii/S1462901113000932".

Rofi, A., Doocy, S., Robinson, C., 2006. Tsunami mortality and displacement in Aceh province, Indonesia. Disasters 30 (3), 340-350.

Stephan, V., 2005. Chernobyl: poverty and stress pose 'bigger threat' than radiation. Nature 437 (7056), 181-181.

Strand, Strand, P., Brynildsen, L., Harbitz, O., Tveten, U., 1989. Measures introduced in Norway after the Chernobyl accident: a cost-benefit analysis. Proceedings Series. 
Table 1: Summary statistics

\begin{tabular}{lll} 
Variable & Mean & Standard Deviation \\
\hline Going back? (0=no; 1= yes) & 0.38 & 0.49 \\
Exclusion zone ( $0=$ no; $1=$ yes) & 0.29 & 0.45 \\
Location (1= same town; $2=$ elsewhere) & 1.42 & 0.49 \\
Radiation level (mSv/year) & 20.5 & 37.5 \\
Deathrate (per 1,000) & 0.01 & 0.01 \\
Tsunami affected town (0=no; 1=yes) & 0.88 & 0.32 \\
Number of school aged children & 1.34 & 0.95 \\
Age & 53.9 & 12.4 \\
Gender (male=1; female=0) & 0.45 & 0.5 \\
Number of elderly in household & 1.76 & 0.79 \\
Nursing care (1=yes; $2=$ no) & 1.93 & 0.26 \\
Length of residence (years) & 34.4 & 20.1 \\
Community participation (1-3; 1 is highest level) & 2.26 & 0.85 \\
Income, (million Yen per year) & 3.22 & 2.37 \\
\hline
\end{tabular}


Table 2. Estimation

\begin{tabular}{|c|c|c|c|c|c|c|}
\hline Variables & Simple & Radiation & Interactive & Can return & Fukushima & IV \\
\hline Location & $\begin{array}{c}0.464 * * \\
(0.185)\end{array}$ & $\begin{array}{c}0.472 * * \\
(0.189)\end{array}$ & $\begin{array}{c}0.506^{* * *} \\
(0.195)\end{array}$ & $\begin{array}{c}0.423 * * \\
(0.186)\end{array}$ & $\begin{array}{c}0.373 \\
(0.273)\end{array}$ & $\begin{array}{l}0.222 * * \\
(0.090)\end{array}$ \\
\hline Tsunami town & $\begin{array}{c}-0.715^{* * *} \\
(0.267)\end{array}$ & $\begin{array}{c}-0.724 * * * \\
(0.275)\end{array}$ & $\begin{array}{c}-0.747 * * * \\
(0.280)\end{array}$ & $\begin{array}{c}-0.769 * * * \\
(0.272)\end{array}$ & $\begin{array}{c}-0.674 * * * \\
(0.242)\end{array}$ & $\begin{array}{l}-0.239 * * * \\
(0.092)\end{array}$ \\
\hline Exclusion zone & $\begin{array}{c}0.592 * * \\
(0.291)\end{array}$ & $\begin{array}{c}0.593 * * \\
(0.291)\end{array}$ & $\begin{array}{c}0.604 * * \\
(0.295)\end{array}$ & $\begin{array}{c}0.551 * * \\
(0.232)\end{array}$ & $\begin{array}{l}0.519^{*} \\
(0.269)\end{array}$ & $\begin{array}{l}0.206 * * \\
(0.097)\end{array}$ \\
\hline Death-rate (D) & $\begin{array}{l}-1.599 \\
(7.308)\end{array}$ & $\begin{array}{l}-1.975 \\
(7.052)\end{array}$ & $\begin{array}{c}68.639 \\
(51.314)\end{array}$ & $\begin{array}{l}-3.191 \\
(6.357)\end{array}$ & $\begin{array}{l}-20.018 \\
(31.891)\end{array}$ & $\begin{array}{l}-0.356 \\
(2.139)\end{array}$ \\
\hline Radiation level (R) & $\begin{array}{c}-0.010 * * * \\
(0.002)\end{array}$ & $\begin{array}{c}0.005 \\
(0.008)\end{array}$ & $\begin{array}{c}0.010 \\
(0.009)\end{array}$ & $\begin{array}{c}0.011 \\
(0.010)\end{array}$ & $\begin{array}{c}0.008 \\
(0.011)\end{array}$ & $\begin{array}{l}0.001 \\
(0.002)\end{array}$ \\
\hline Children & $\begin{array}{l}-0.036 \\
(0.073)\end{array}$ & $\begin{array}{c}0.052 \\
(0.068)\end{array}$ & $\begin{array}{c}0.067 \\
(0.138)\end{array}$ & $\begin{array}{c}0.013 \\
(0.092)\end{array}$ & $\begin{array}{l}-0.112 \\
(0.105)\end{array}$ & $\begin{array}{l}0.012 \\
(0.021)\end{array}$ \\
\hline Age & $\begin{array}{c}0.013 \\
(0.011)\end{array}$ & $\begin{array}{c}0.015 \\
(0.012)\end{array}$ & $\begin{array}{c}0.036^{* * * *} \\
(0.014)\end{array}$ & $\begin{array}{l}0.023^{*} \\
(0.013)\end{array}$ & $\begin{array}{l}0.033^{*} \\
(0.018)\end{array}$ & $\begin{array}{l}0.005 \\
(0.004)\end{array}$ \\
\hline Number of elderly & $\begin{array}{l}-0.032 \\
(0.087)\end{array}$ & $\begin{array}{c}0.009 \\
(0.099)\end{array}$ & $\begin{array}{l}-0.233^{*} \\
(0.129)\end{array}$ & $\begin{array}{l}-0.012 \\
(0.086)\end{array}$ & $\begin{array}{l}-0.067 \\
(0.158)\end{array}$ & $\begin{array}{l}0.004 \\
(0.032)\end{array}$ \\
\hline Death x Child & & & $\begin{array}{l}-2.276 \\
(8.673)\end{array}$ & & & \\
\hline Death x Age & & & $\begin{array}{c}-1.706^{* * *} \\
(0.724)\end{array}$ & & & \\
\hline Death $\mathrm{x}$ elderly & & & $\begin{array}{c}16.447 * * * \\
(5.917)\end{array}$ & & & \\
\hline Radiation $\mathrm{x}$ child & & $\begin{array}{c}-0.004 * * * \\
(0.001)\end{array}$ & $\begin{array}{c}-0.004 * * * \\
(0.001)\end{array}$ & $\begin{array}{c}-0.004 * * \\
(0.001)\end{array}$ & $\begin{array}{l}-0.002 * \\
(0.001)\end{array}$ & $\begin{array}{l}-0.001 * * * \\
(0.000)\end{array}$ \\
\hline Radiation $\mathrm{x}$ age & & $\begin{array}{r}-0.0001 \\
(0.000)\end{array}$ & $\begin{array}{r}-0.0002 \\
(0.000)\end{array}$ & $\begin{array}{c}-0.003 \\
(0.000)\end{array}$ & $\begin{array}{l}-0.003 \\
(0.000)\end{array}$ & $\begin{array}{l}-0.000 \\
(0.000)\end{array}$ \\
\hline Radiation x elderly & & $\begin{array}{l}-0.002 \\
(0.002)\end{array}$ & $\begin{array}{l}-0.001 \\
(0.002)\end{array}$ & $\begin{array}{l}-0.002 \\
(0.002)\end{array}$ & $\begin{array}{l}-0.0002 \\
(0.003)\end{array}$ & $\begin{array}{l}-0.001 \\
(0.001)\end{array}$ \\
\hline Gender & $\begin{array}{c}0.037 \\
(0.141)\end{array}$ & $\begin{array}{c}0.006 \\
(0.137)\end{array}$ & $\begin{array}{l}-0.001 \\
(0.138)\end{array}$ & $\begin{array}{c}0.052 \\
(0.139)\end{array}$ & $\begin{array}{l}-0.020 \\
(0.220)\end{array}$ & $\begin{array}{l}0.010 \\
(0.046)\end{array}$ \\
\hline Nursing Care & $\begin{array}{c}0.326 \\
(0.238)\end{array}$ & $\begin{array}{c}0.351 \\
(0.243)\end{array}$ & $\begin{array}{c}0.369 \\
(0.242)\end{array}$ & $\begin{array}{c}0.204 \\
(0.249)\end{array}$ & $\begin{array}{l}-0.017 \\
(0.263)\end{array}$ & $\begin{array}{l}0.102 \\
(0.065)\end{array}$ \\
\hline Length of residence & $\begin{array}{c}0.000 \\
(0.005)\end{array}$ & $\begin{array}{c}0.001 \\
(0.005)\end{array}$ & $\begin{array}{c}0.002 \\
(0.005)\end{array}$ & $\begin{array}{l}-0.002 \\
(0.006)\end{array}$ & $\begin{array}{l}-0.003 \\
(0.005)\end{array}$ & $\begin{array}{l}0.000 \\
(0.002)\end{array}$ \\
\hline Income, million Yen & $\begin{array}{c}0.069 * * \\
(0.032)\end{array}$ & $\begin{array}{c}0.073^{* *} \\
(0.033)\end{array}$ & $\begin{array}{c}0.077 * * \\
(0.033)\end{array}$ & $\begin{array}{l}0.053^{*} \\
(0.030)\end{array}$ & $\begin{array}{c}0.043 \\
(0.042)\end{array}$ & $\begin{array}{l}0.025 * * \\
(0.010)\end{array}$ \\
\hline Community & $\begin{array}{l}-0.098 \\
(0.099)\end{array}$ & $\begin{array}{l}-0.103 \\
(0.100)\end{array}$ & $\begin{array}{l}-0.116 \\
(0.103)\end{array}$ & $\begin{array}{l}-0.098 \\
(0.105)\end{array}$ & $\begin{array}{l}-0.061 \\
(0.105)\end{array}$ & $\begin{array}{l}-0.038 \\
(0.032)\end{array}$ \\
\hline Miyagi (dummy) & $\begin{array}{l}-0.176 \\
(0.394)\end{array}$ & $\begin{array}{l}-0.151 \\
(0.396)\end{array}$ & $\begin{array}{l}-0.170 \\
(0.407)\end{array}$ & $\begin{array}{l}-0.220 \\
(0.320)\end{array}$ & & $\begin{array}{l}-0.045 \\
(0.133)\end{array}$ \\
\hline Constant & $\begin{array}{c}-1.466^{*} \\
(0.868) \\
\end{array}$ & $\begin{array}{c}-1.833 * * \\
(0.855) \\
\end{array}$ & $\begin{array}{c}-2.694^{* *} \\
(1.186) \\
\end{array}$ & $\begin{array}{c}-1.587^{*} \\
(0.901) \\
\end{array}$ & $\begin{array}{l}-1.280 \\
(1.038) \\
\end{array}$ & $\begin{array}{l}-0.154 \\
(0.297) \\
\end{array}$ \\
\hline Marginal effect of $\mathrm{R}$ & $\begin{array}{c}-0.0032^{* * * *} \\
(0.00068)\end{array}$ & $\begin{array}{c}-0.0031 * * * \\
(0.00087)\end{array}$ & $\begin{array}{c}-0.0031^{* * *} \\
(0.00089)\end{array}$ & $\begin{array}{c}-0.0035^{* * * *} \\
(0.00086)\end{array}$ & $\begin{array}{c}-0.0032 * * * \\
(0.00098)\end{array}$ & $\begin{array}{c}-0.0034^{* * *} * \\
(0.00082)\end{array}$ \\
\hline Observations & 520 & 520 & 520 & 406 & 265 & 520 \\
\hline 11 & -302.3 & -299.5 & -295.9 & -231.9 & -156.2 & - \\
\hline LR tests ( $p$-value) & - & 0.127 & 0.066 & - & - & - \\
\hline
\end{tabular}

Standard errors clustered at city level, in parentheses; ${ }^{* * *} \mathrm{p}<0.01,{ }^{* *} \mathrm{p}<0.05,{ }^{*} \mathrm{p}<0.1$ 


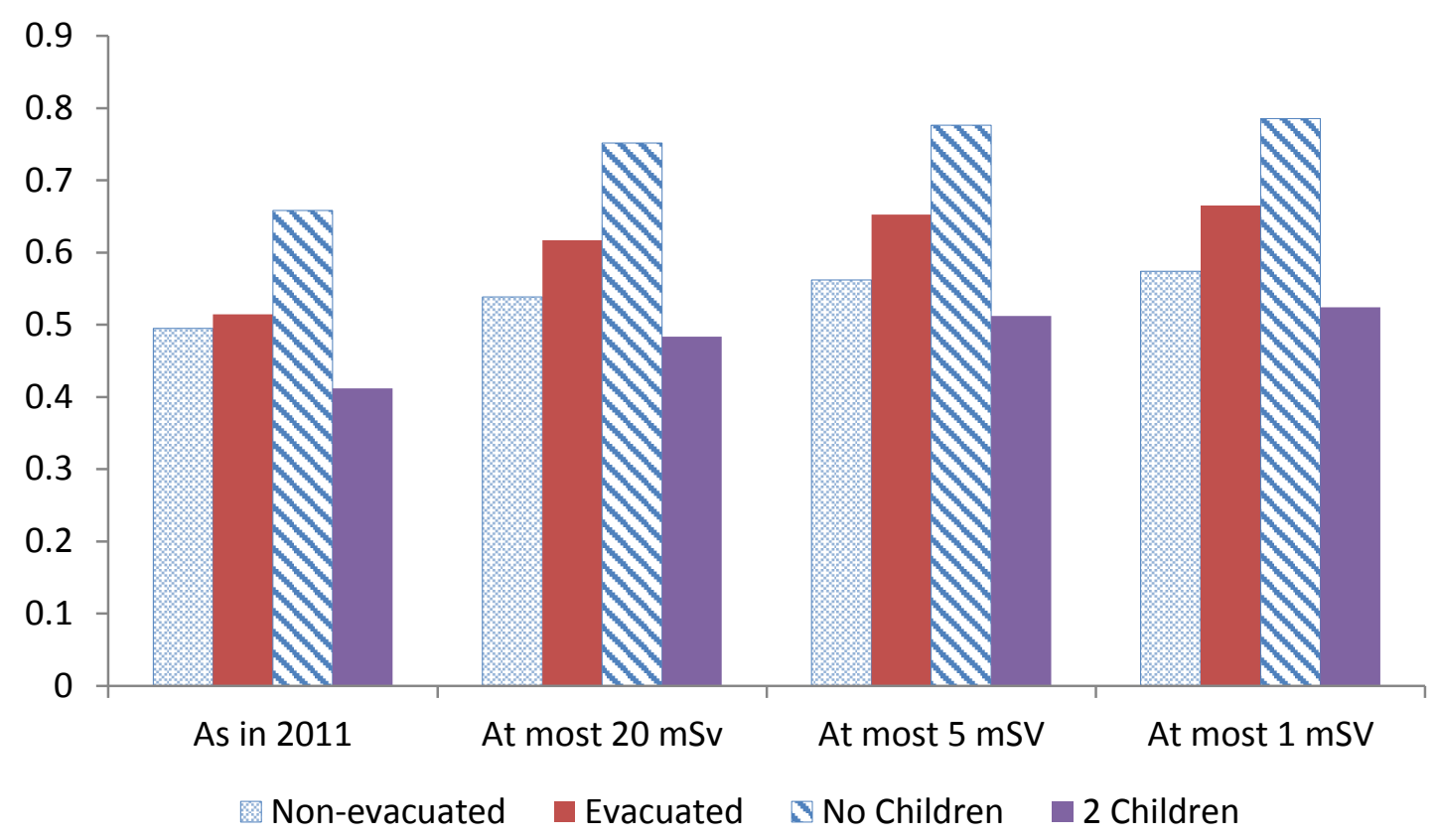

Figure 1. Intention to return by target maximum dose

Note: Four policies on return intentions are shown in horizontal axis labelled as the baseline (Policy 1: based on the 2011 radiation levels), reduced to a maximum of $20 \mathrm{mSv}$ (Policy 2), $5 \mathrm{mSv}$ (Policy 3) and $1 \mathrm{mSv}$ (Policy 4). 